\title{
Effects of nociceptin (13-17) in pain modulation at supraspinal level in mice
}

\author{
Li-Xiang Chen, Zhuan-Zi Wang, Hua Wu, Quan Fang, Yong Chen, Rui Wang* \\ Department of Biochemistry and Molecular Biology, School of Life Science, Lanzhou University, 298 Tian Shui Road, Lanzhou, 730000, \\ Peoples Republic of China
}

Received 16 April 2002; received in revised form 1 July 2002; accepted 24 July 2002

\begin{abstract}
This work was designed to observe the effects of nociceptin(13-17), one of the main metabolites of nociceptin (also termed orphanin FQ), in pain modulation at supraspinal level in mice. Intracerebroventricular (i.c.v.) administration of nociceptin/orphanin $\mathrm{FQ}(13-17)$ (N/OFO(13-17)) $(5,0.5,0.05,0.005 \mathrm{nmol} /$ mouse) dose-dependently induced potent hyperalgesic effects in the $48{ }^{\circ} \mathrm{C}$ warm-water tail-flick test in mice. I.c.v. pretreatment with N/OFO(13-17) $(5,0.5,0.05 \mathrm{nmol} /$ mouse) potentiated the analgesic effects induced by morphine (i.p., $2 \mathrm{mg} / \mathrm{kg}$ ) and reversed the hyperalgesic effects induced by N/OFO (i.c.v., $5 \mathrm{nmol} /$ mouse). The hyperalgesic effects induced by N/OFO(13-17) could not be antagonized by [Nphe']N/OFO(1-13) $\mathrm{NH}_{2}$ or naloxone. These findings suggest that N/OFO(13-17) may play important roles in pain modulation at supraspinal level in mice and elicits these effects through a novel mechanism independent of the N/OFO receptor and the $\mu, \delta$ and $\kappa$ opioid receptors. () 2002 Elsevier Science Ireland Ltd. All rights reserved.
\end{abstract}

Keywords: Nociceptin/orphanin FQ(13-17); Intracerebroventricular; Hyperalgesia; Nociceptin/orphanin FQ; [Nphe $\left.{ }^{1}\right]$ Nociceptin/orphanin $\mathrm{FQ}(1-13) \mathrm{NH}_{2}$; Naloxone; Morphine; Mice

Nociceptin/orphanin FQ (N/OFQ), a heptadecapeptide (Phe-Gly-Gly-Phe-Thr-Gly-Ala-Arg-Lys-Ser-Ala-Arg-LysLeu-Ala-Asn-Gln), has been recently identified as the endogenous ligand of the N/OFQ receptor (NOPR) [6,11]. Although structurally similar to the endogenous opioid peptide (especially dynorphin A), N/OFQ possesses different characteristics in pharmacological profiles in that it binds to the traditional opioid receptors $(\mu, \delta$ and $\kappa)$ with very low affinity $[6,11]$. It has been demonstrated that $\mathrm{N} /$ OFQ exhibits both hyperalgesic and analgesic effects. Hyperalgesic effects of N/OFQ were observed after intracerebroventricular (i.c.v.) or intrathecal (i.t.) injection of $\mathrm{N} /$ OFQ in the mouse hot-plate and tail-flick assays [4,6,11]. Some studies revealed that N/OFQ administered supraspinally produced an initial hyperalgesic response followed by analgesia in mice [13,14]. Analgesic actions of N/OFQ have been found repeatedly after i.t. or microiontophoretical injection of N/OFQ in rats [17-19]. Flores et al. demonstrated that the effects of N/OFQ were sex-specific in rats i.e. it produced antinociceptive effects in the male and

\footnotetext{
* Corresponding author. Tel: +86-931-8912567; fax: +86-9318912561.

E-mail address: wangrui@Izu.edu.cn (R. Wang).
}

pronociceptive effects in the female [2]. It was also reported that N/OFQ showed anti-opioid activities at the supraspinal level in the rats [7]. Moreover, it has been reported that some metabolites of N/OFQ played important roles in pain modulation. For example, the $\mathrm{N}$ terminal fragments of N/OFQ, N/OFQ(1-7) and N/OFQ(1-11), were demonstrated to antagonize the pronociceptive effects induced by N/OFQ $[15,16]$. Therefore, the $\mathrm{N}$ terminal fragments may modulate the action of N/OFQ. However, there are few reports on the pharmacological activities induced by $\mathrm{C}$ terminal fragments. N/OFQ(13-17), a C-terminal fragment of $\mathrm{N} / \mathrm{OFQ}$, has been found to elicit nociceptive responses in the peripheral nociceptors and in the spinal cord in mice [5]. In this study, to investigate the involvement of N/OFQ(1317) in pain regulation at the supraspinal level, we examined the effects of i.c.v. administration of N/OFQ(13-17) on pain behavior, morphine-induced analgesia and N/OFQ-induced hyperalgesia with the tail-flick assay in mice.

Male ddY mice (20-22 g) were supplied by the Animal Center of Lanzhou Medical College. They had free access to food and water in an animal room which was maintained at $22 \pm 1{ }^{\circ} \mathrm{C}$ with a $12 \mathrm{~h}$ light/dark cycle. Every mouse was used only once. The peptides used in this study: N/OFQ; $\mathrm{N} / \mathrm{OFQ}(13-17)$; and [Nphe $] \mathrm{N} / \mathrm{OFQ}(1-13) \mathrm{NH}_{2}$ were synthe- 


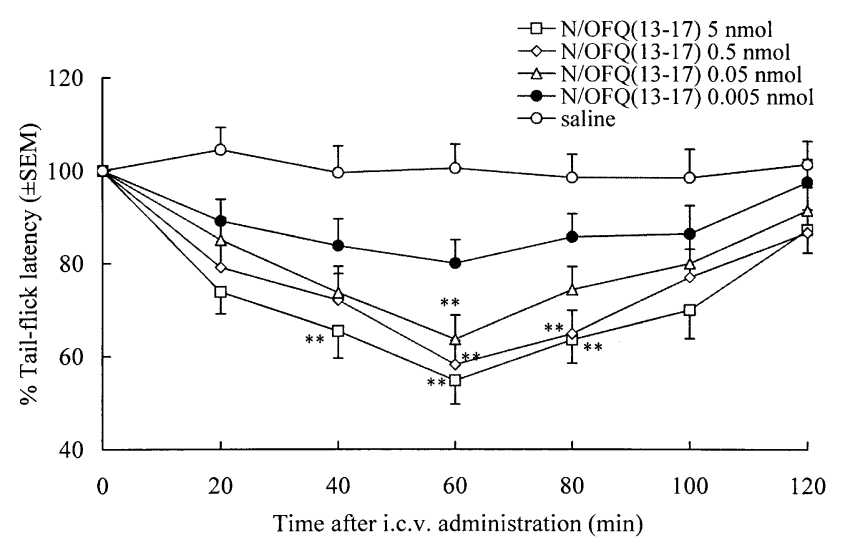

Fig. 1. Effects of i.c.v. administration of N/OFQ(13-17) in tail-flick test in mice. N/OFQ(13-17) produced a hyperalgesic effect. Each time point is presented as $\% \mathrm{TFL} \pm \operatorname{SEM}(n=15)$. ${ }^{*} P<0.01$, compared with the saline group.

sized by solid-phase peptide synthesis method and purified by high-performance liquid chromatography by our group. All the drugs were dissolved in sterilized saline. Morphine hydrochloride and naloxone were the products of Shenyang First Pharmaceutical Factory in China.

The effects of N/OFQ(13-17) were assessed with the $48^{\circ} \mathrm{C}$ warm-water tail-flick test. The latency to the first sign of a rapid tail-flick was taken as the behavioral end point. Every mouse was first tested for baseline latency by immersing its tail in the water and recording the response time. Effects of drugs were tested with tail-flick reflex every 10 min for 120 min post-injection. The average tail-flick latency (TFL) of each group of mice before administration served as the control $(100 \%)$. Results were calculated with the following equation: $\% \mathrm{TFL}=100 \times($ test TFL/control TFL) $\pm \mathrm{SEM}$. Data have been statistically analyzed with analysis of variance followed by the LSD post-hoc test; $P$-values less

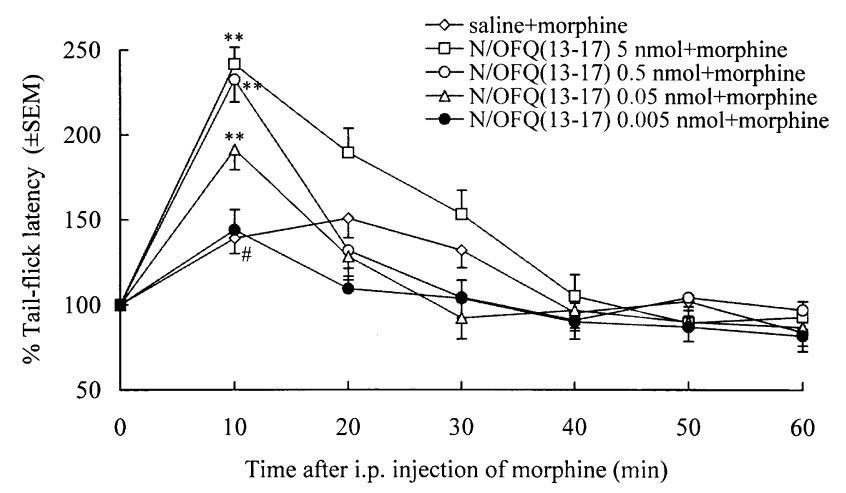

Fig. 2. Effects of N/OFQ(13-17) on morphine-induced analgesia. Mice were injected i.c.v. with N/OFQ(13-17), 5 min later, morphine $(2 \mathrm{mg} / \mathrm{kg})$ was injected i.p. Pretreatment with $\mathrm{N} /$ OFQ(13-17) enhanced morphine-induced analgesia, and pretreatment with saline showed no effects on it. Each time point is presented as \%TFL \pm SEM $(n=10)$. ${ }^{* *} P<0.01$, compared with the saline + morphine group; $\# P<0.05$, compared with the saline group (data of saline not shown).

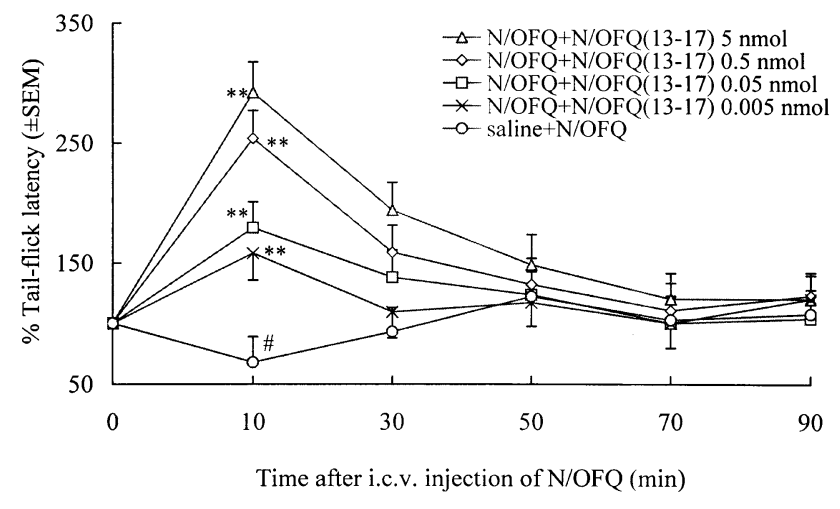

Fig. 3. Effects of N/OFQ(13-17) on N/OFQ-induced hyperalgesia. Mice were injected i.c.v. with N/OFQ(13-17), 5 min later, N/OFO $(5 \mathrm{nmol} / \mathrm{mouse}$ ) was injected i.c.v.. Pretreatment with N/OFQ(1317) reversed the N/OFQ-induced hyperalgesia, and pretreatment with saline showed no effects on it. Each time point is presented as $\% \mathrm{TFL} \pm \operatorname{SEM}(n=10) .{ }^{*} P<0.01$, compared with the saline $+\mathrm{N} / \mathrm{OFQ}$ group; $\# P<0.05$, compared with saline group (data of saline not shown).

than 0.05 were considered to be significant. A cut-off latency of $30 \mathrm{~s}$ was used, animals that did not respond within the cutoff time were removed to avoid tissue damage.

The i.c.v. administration was performed following the method described by Haley and McCormick (1957) [3]. Briefly, under light ether anesthesia, an incision was made in the scalp. The injection site was $1.5 \mathrm{~mm}$ from the midline, $0 \mathrm{~mm}$ from the bregma and $3.0 \mathrm{~mm}$ from the surface of the skull. Drugs were administrated in a volume of $5 \mu \mathrm{l}$ at a constant rate of $10 \mu \mathrm{l} / \mathrm{min}$. Proper injection site was verified in pilot experiments by administration and localization of methylene blue dye. To test the effects of N/OFQ(13-17) on morphine-induced analgesia or N/OFQ-induced hyperalgesia, N/OFQ(13-17) was administrated $5 \mathrm{~min}$ before the intraperitoneal (i.p.) injection of morphine or the i.c.v. injection of N/OFQ. To investigate whether or not the hyperalgesic effects of $\mathrm{N} / \mathrm{OFQ}(13-17)$ could be antagonized by [Nphe $] \mathrm{N} / \mathrm{OFQ}(1-13) \mathrm{NH}_{2}$ or naloxone, antagonists were pre-injected respectively $5 \mathrm{~min}$ before the i.c.v. administration of N/OFQ(13-17).

The i.c.v. administration of N/OFQ(13-17) $(5,0.5,0.05$, $0.005 \mathrm{nmol} / \mathrm{mouse}$ ) produced a significant decrease in tail withdrawal latencies. I.c.v. injection of saline did not significantly alter the TFL. This dose-dependent hyperalgesic effect of N/OFQ(13-17) was evoked 10 min after injection, reached a maximum at about $60 \mathrm{~min}$ and terminated at 120 min. I.c.v. injection of $5 \mathrm{nmol} /$ mouse of $\mathrm{N} / \mathrm{OFQ}(13-17)$ caused a reduction of $45.2 \pm 5.12 \%$ at $60 \mathrm{~min}$ post-injection (vs. saline group, $P<0.01)$. Low dose $(0.005 \mathrm{nmol} / \mathrm{mouse})$ of N/OFQ(13-17) did not produce a significant hyperalgesic effect (Fig. 1).

N/OFQ(13-17) administered 5 min before i.p. injection of morphine $(2 \mathrm{mg} / \mathrm{kg})$ enhanced the morphine-induced analgesia in a dose-dependent manner and showed no hyperalgesic activity. At a dose of $5 \mathrm{nmol} / \mathrm{mouse}, \mathrm{N} /$ 


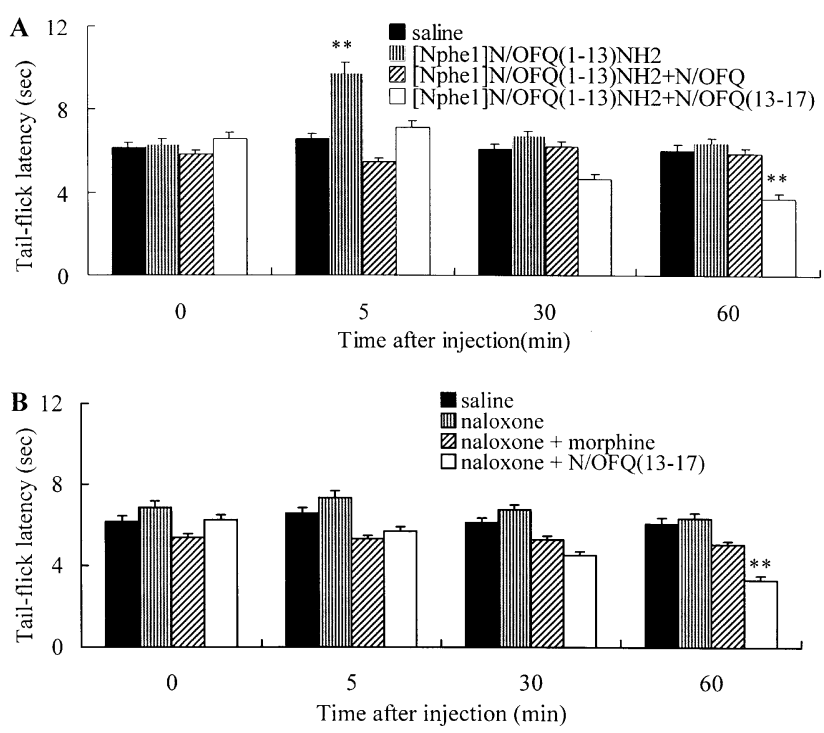

Fig. 4. Effects of i.c.v. preinjection of [Nphe $\left.{ }^{1}\right] \mathrm{N} / \mathrm{OFQ}(1-13) \mathrm{NH}_{2}(A)$ or s.c. preinjection of naloxone (B) on hyperalgesic effects of $\mathrm{N} /$ OFQ(13-17). Mice were injected i.c.v. with [Nphe ${ }^{1}$ ]N/OFQ(113) $\mathrm{NH}_{2}(5 \mathrm{nmol})$ alone or following i.c.v. injection of N/OFO (5 $\mathrm{nmol}$ ) or N/OFQ(13-17) $(5 \mathrm{nmol})(\mathrm{A})$. Naloxone $(2 \mathrm{mg} / \mathrm{kg})$ was injected s.c. alone or following the administration of morphine (i.p., $2 \mathrm{mg} / \mathrm{kg}$ ) or N/OFO(13-17) (i.c.v., $5 \mathrm{nmol}$ ) (B). Assessment of TFL was made at 5, 30,60 min. Data were expressed as TFL \pm SEM $(n=10) .{ }^{*} P<0.01$, compared with the saline group.

OFQ(13-17) significantly enhanced the analgesic effect elicited by morphine, the peak was observed $10 \mathrm{~min}$ after i.p. injection of morphine $(104.56 \pm 9.77 \%$ enhancement vs. saline + morphine group, $P<0.01)$. However, low dose $(0.005 \mathrm{nmol} /$ mouse $)$ of $\mathrm{N} / \mathrm{OFQ}(13-17)$ could not potentiate the analgesia of morphine (vs. saline + morphine group, $P>0.05$ ) (Fig. 2).

Pretreatment with N/OFQ(13-17) (5, 0.5, 0.05, 0.005 $\mathrm{nmol} /$ mouse) reversed the hyperalgesia induced by N/OFQ and showed potent analgesic effects. The reversing effects of $\mathrm{N} / \mathrm{OFQ}(13-17)$ peaked at $10 \mathrm{~min}$ after injection of $\mathrm{N} /$ OFQ and lasted for about $50 \mathrm{~min}$. The maximal effect was observed when $5 \mathrm{nmol} /$ mouse of N/OFQ(13-17) was preinjected $(224.0 \pm 25.43 \%$ reversion vs. saline $+\mathrm{N} / \mathrm{OFQ}$ group, $P<0.01$ ) (Fig. 3).

[Nphe $] \mathrm{N} / \mathrm{OFQ}(1-13) \mathrm{NH}_{2}(5 \mathrm{nmol})$ injected i.c.v. alone produced significant analgesia, which peaked at $5 \mathrm{~min}$ and terminated at $30 \mathrm{~min}$. When [Nphe $] \mathrm{N} / \mathrm{OFQ}(1-13) \mathrm{NH}_{2}$ was pre-injected, either the hyperalgesic effect of N/OFQ or the analgesic effect of [Nphe $] \mathrm{N} / \mathrm{OFQ}(1-13) \mathrm{NH}_{3}$ were not evident. However, pretreatment with $[\mathrm{Nphe}] \mathrm{N} / \mathrm{OFQ}(1-$ 13) $\mathrm{NH}_{2}$ did not influence the hyperalgesic effects of $\mathrm{N} /$ OFQ(13-17) (i.c.v., $5 \mathrm{nmol}$ ) (Fig. 4A). Naloxone injected subcutaneously (s.c.) alone did not influence the baseline TFL. Pre-injection of naloxone $(2 \mathrm{mg} / \mathrm{kg})$ antagonized the morphine (i.p., $2 \mathrm{mg} / \mathrm{kg}$ ) analgesia, but did not affect the hyperalgesia induced by N/OFQ(13-17) (5 nmol) (Fig. 4B).

Monteil et al. have reported that N/OFQ is metabolized by aminopeptidase $\mathrm{N}$ and endopeptidase 24.15 in mouse brain cortical slices, and forms five main fragments: $\mathrm{N} /$ OFQ(1-7), N/OFQ(2-17), N/OFQ(1-11), N/OFQ(12-17), $\mathrm{N} / \mathrm{OFQ}(13-17)$ [8]. Although there are many reports on the physiological activities of the $\mathrm{N}$ terminal metabolites of N/OFQ, few studies on the activities of $\mathrm{C}$ terminal metabolites of N/OFQ are reported. The present study is the first to demonstrate that $\mathrm{N} / \mathrm{OFQ}(13-17)$ plays an important role in pain modulation at supraspinal level in mice.

$\mathrm{N} / \mathrm{OFQ}$ injected i.c.v. has been reported to produce hyperalgesic effects, i.e. it reduced the tail flick [11] or hot plate response latency in mice [6]. Subsequent studies found that i.c.v. N/OFQ was able to elicit both a rapid hyperalgesia and a delayed analgesia in mice in the tail-flick assay $[13,14]$. Our results are consistent with these reports. In the present study, we found i.c.v. administration of the $\mathrm{C}$ terminal fragment of N/OFQ, N/OFQ(13-17), produced potent hyperalgesic effects in the tail-flick test, but it did not induce delayed analgesia. [Nphe ${ }^{1} \mathrm{~N} / \mathrm{OFQ}(1-13) \mathrm{NH}_{2}$ was first reported by Rizzi et al. as an antagonist of NOP in mouse colon assay and the selective and competitive antagonistic effect was demonstrated in a variety of in vitro preparations and in vivo [10,12]. [Nphe $] \mathrm{N} / \mathrm{OFQ}(1-13) \mathrm{NH}_{2}$ injected i.c.v. alone was found to induce an antinociceptive effect which was attributed to block of NOP; when [Nphe ] $\mathrm{N} /$ $\mathrm{OFQ}(1-13) \mathrm{NH}_{2}$ was given together with $\mathrm{N} / \mathrm{OFQ}$, it was found to reverse the hyperalgesia of N/OFQ in mice [1]. Naloxone is widely accepted as an antagonist at classical opioid receptor. In the present study, we found that [Nphe $] \mathrm{N} / \mathrm{OFQ}(1-13) \mathrm{NH}_{2}$ and naloxone did not antagonize the supraspinal effects of $\mathrm{N} / \mathrm{OFQ}(13-17)$. We suggest that N/OFQ(13-17) elicits its hyperalgesic effects through a novel mechanism independent of the NOP and the $\mu, \delta$ and $\kappa$ opioid receptors.

We also found N/OFQ(13-17) possessed some effects different from N/OFQ. It could reverse N/OFQ-induced hyperalgesia. These findings imply there may be a complex interaction between N/OFQ and N/OFQ(13-17) by which $\mathrm{N} / \mathrm{OFQ}(13-17)$ reverses the hyperalgesic effects of N/OFQ and produces potent analgesic effects. Moreover, N/ $\mathrm{OFQ}(13-17)$ was found to potentiate morphine-induced analgesic effects. It is well known that morphine elicits analgesic effects by acting at the traditional opioid receptors. In the present study, we demonstrated N/OFQ(13-17) did not produce its effects via acting at $\mu, \delta$ and $\kappa$ receptors. Therefore, it is possible that morphine induced activation of the traditional opioid receptors was reinforced by $\mathrm{N} /$ OFQ(13-17). However, the mechanism underlying the effects of N/OFQ(13-17) in pain modulation in mice need to be studied further.

In conclusion, $\mathrm{N} / \mathrm{OFQ}(13-17)$, a principal metabolite of $\mathrm{N} / \mathrm{OFQ}$, has been demonstrated to play complex roles in pain modulation at supraspinal level in mice. Its effects may be elicited via a different mechanism that nevertheless can be physiologically relevant with N/OFQ. Further, it has been demonstrated that all the effects of N/OFQ are no longer evident in mice knockout for the NOP gene [9]. 
Together these observations raise important concerns about the physiological relevance of the fragments of N/OFQ.

This work was supported by the National Natural Science Foundation of China (No. 20072014) and the Teaching and Research Award Program for Outstanding Young Teachers in Higher Education Institutions of Ministry of Education of China.

[1] Calo, G., Guerrini, R., Bigoni, R., Rizzi, A., Marzola, G., Okawa, H., Bianchi, C., Lambert, D.G., Salvadori, S. and Regoli, D., Characterization of [Nphe $\left.{ }^{1}\right]$ nociceptin(113) $\mathrm{NH}_{2}$, a new selective nociceptin receptor antagonist, Br. J. Pharmacol., 129 (2000) 1183-1193.

[2] Flores, C.A., Wang, X.M., Zhang, K.M. and Mokha, S.S., Orphanin FO produces gender-specific modulation of trigeminal nociception: behavioral and electrophysiological observations, Neuroscience, 105 (2001) 489-498.

[3] Haley, T.J. and McCormick, W.G., Pharmacological effects produced by intracerebral injections of drugs in the conscious mouse, Br. J. Pharmacol., 12 (1957) 12-15.

[4] Hara, N., Minami, T., Okuda-Ashitaka, E., Sugimoto, T., Sakai, M., Onaka, M., Mori, H., Imanishi, T., Shingu, K. and Ito, S., Characterization of nociceptin hyperalgesia and allodynia in conscious mice, Br. J. Pharmacol., 121 (1997) 401-408.

[5] Inoue, M., Matsunaga, S., Rashid, M.H., Yoshida, A., Mizuno, K., Sakurada, T., Takeshima, H. and Ueda, H., Pronociceptive effects of nociceptin/orphanin FQ (13-17) at peripheral and spinal level in mice, J. Pharmacol. Exp. Ther., 299 (2001) 213-219.

[6] Meunier, J.C., Mollereau, C., Tool, L., Suaudeau, C., Moisand, C., Alvinerie, P., Butour, J.L., Guillemot, J.C., Ferrara, P., Monsarrat, B., Mazarguil, H., Vassart, G., Parmentier, M. and Costentin, J., Isolation and structure of the endogenous agonist of opioid receptor-like ORL1 receptor, Nature, 377 (1995) 532-535.

[7] Mogil, J.S., Grisel, J.E., Reinscheid, R.K., Civelli, O., Belknap, J.K. and Grandy, D.K., Orphanin FQ is a functional anti-opioid peptide, Neuroscience, 75 (1996) 333-337.

[8] Monteil, J.L., Cornille, F., Roques, B.P. and Noble, F., Nociceptin/orphanin FQ metabolism: role of aminopeptidase and endopeptidase 24.15, J. Neurochem., 68 (1997) 354361.

[9] Nishi, M., Houtani, T., Noda, Y., Mamiya, T., Sato, K., Doi, T., Kuno, J., Takeshima, H., Nukada, T., Nabeshima, T., Yamashita, T., Noda, T. and Sugimoto, T., Unrestrained nociceptive response and disregulation of hearing ability in mice lacking the nociceptin/orphanin FO receptor, EMBOJ., 16 (1997) 1858-1864.

[10] Polidori, C., Calo, G., Ciccocioppo, R., Guerrini, R., Regoli, D. and Massi, M., Pharmacological characterization of the nociceptin receptor mediating hyperphagia: identification of a selective antagonist, Psychopharmacology (Berlin), 148 (2000) 430-437.

[11] Reinscheid, R.K., Nothacker, H.P., Bourson, A., Ardati, A., Hernningsen, R.A., Bunzow, J.R., Grandy, D.K., Langen, H., Monsma, F.J. and Civelli, O., Orphanin FQ: a neuropeptide that activates an opioid-like $\mathrm{G}$ protein- coupled receptor, Science, 270 (1995) 792-794.

[12] Rizzi, A., Bigoni, R., Calo, G., Guerrini, R., Salvadori, S. and Regoli, D., [Nphe ${ }^{1}$ ]nociceptin-(1-13) $\mathrm{NH}_{2}$ antagonizes nociceptin effects in the mouse colon, Eur. J. Pharmacol., 385 (1999) R3-R5.

[13] Rossi, G.C., Leventhal, L., Bolan, E. and Pasternak, G.W., Pharmacological characterization of orphanin FQ/nociceptin and its fragments, J. Pharmacol. Exp. Ther., 282 (1997) 858-865.

[14] Rossi, G.C., Leventhal, L. and Pasternak, G.W., Naloxone sensitive orphanin FQ-induced analgesia in mice, Eur. J. Pharmacol., 311 (1996) R7-R8.

[15] Sakurada, T., Sakurada, S., Katsuyama, S., Sakurada, C., Tan-No, K. and Terenius, L., Nociceptin (1-7) antagonizes nociceptin-induced hyperalgesia in mice, Br. J. Pharmacol., 128 (1999) 941-944.

[16] Sakurada, T., Sakurada, S., Katsuyama, S., Hayashi, T., Sakurada, C., Tan-No, K., Johansson, H., Sandin, J. and Terenius, L., Evidence that N-terminal fragments of nociceptin modulate nociceptin-induced scratching, biting and licking in mice, Neurosci. Lett., 279 (2000) 61-64.

[17] Stanfa, L.C., Chapman, V., Kerr, N. and Dickenson, A.H., Inhibitory action of nociceptin on spinal dorsal horn neurones of the rat, in vivo, Br. J. Pharmacol., 118 (1996) 1875-1877.

[18] Wang, X.M., Zhang, K.M., Long, L.O. and Mokha, S.S., Orphanin FQ (nociceptin) modulates responses of trigeminal neurons evoked by excitatory amino acids and somatosensory stimuli, and blocks the substance P-induced facilitation of $\mathrm{N}$-methyl-D-aspartate-evoked responses, Neuroscience, 93 (1999) 703-712.

[19] Yamamoto, T., Nozaki-Taguchi, N. and Kimura, S., Effects of intrathecally administered nociceptin, an opioid receptor-like $_{1}\left(O \mathrm{OL}_{1}\right)$ receptor agonist, on the thermal hyperalgesia induced by unilateral constriction injury to the sciatic nerve in the rat, Neurosci. Lett., 224 (1997) 107-110. 